\title{
Moniliella spathulata, an oil-degrading yeast, which promotes growth of barley in oil-polluted soil
}

\author{
Annett Mikolasch $^{1}$ (D) Ramza Berzhanova ${ }^{2} \cdot$ Anel Omirbekova $^{2} \cdot$ Anne Reinhard $^{1} \cdot$ Daniele Zühlke $^{1} \cdot$ \\ Mareike Meister $^{3} \cdot$ Togzhan Mukasheva $^{2} \cdot$ Katharina Riedel $^{1} \cdot$ Tim Urich $^{1} \cdot$ Frieder Schauer $^{1}$
}

Received: 23 April 2020 / Revised: 5 November 2020 / Accepted: 9 November 2020 / Published online: 20 November 2020

(C) The Author(s) 2020

\begin{abstract}
The yeast strain Moniliella spathulata SBUG-Y 2180 was isolated from oil-contaminated soil at the Tengiz oil field in the Atyrau region of Kazakhstan on the basis of its unique ability to use crude oil and its components as the sole carbon and energy source. This yeast used a large number of hydrocarbons as substrates (more than 150), including $n$-alkanes with chain lengths ranging from $\mathrm{C}_{10}$ to $\mathrm{C}_{32}$, monomethyl- and monoethyl-substituted alkanes $\left(\mathrm{C}_{9}-\mathrm{C}_{23}\right)$, and $n$-alkylcyclo alkanes with alkyl chain lengths from 3 to 24 carbon atoms as well as substituted monoaromatic and diaromatic hydrocarbons. Metabolism of this huge range of hydrocarbon substrates produced a very large number of aliphatic, alicyclic, and aromatic acids. Fifty-one of these were identified by GC/MS analyses. This is the first report of the degradation and formation of such a large number of compounds by a yeast. Inoculation of barley seeds with M. spathulata SBUG-Y 2180 had a positive effect on shoot and root development of plants grown in oil-contaminated sand, pointing toward potential applications of the yeast in bioremediation of polluted soils.
\end{abstract}

\section{Key points}

- Moniliella spathulata an oil-degrading yeast

- Increase of the growth of barley

Keywords Moniliella spathulata $\cdot$ Trichosporonoides spathulata $\cdot$ Crude oil $\cdot$ Biphenyl $\cdot$ Dibenzofuran

\section{Introduction}

The yeast SBUG-Y 2180 was isolated from a sample of oilcontaminated soil from the Tengiz oil field in the Atyrau region of Kazakhstan. The Tengiz oil reservoir was discovered in 1979. It is approximately $21 \mathrm{~km}$ long and $19 \mathrm{~km}$ wide and is one of the largest oil fields worldwide with reserves estimated at between six billion and nine billion barrels (GlobalData.com 2020; Pala

This work is dedicated to the late scientist Frieder Schauer.

Annett Mikolasch

annett.mikolasch@uni-greifswald.de

1 Institute of Microbiology, University Greifswald, Felix-Hausdorff-Straße 8, 17489 Greifswald, Germany

2 Department of Biology and Biotechnology, Al-Farabi Kazakh National University, Al-Farabi Ave 71, Almaty, Kazakhstan 050040

3 Leibniz Institute for Plasma Science and Technology (INP), Felix-Hausdorff-Str. 2, 17489 Greifswald, Germany
2001). It is considered to be the largest single-trap producing reservoir in existence (Chevron.com 2020). There have been a number of accidental spills during the exploitation of this deposit, because the oil is hot and under greater pressure than has been seen at any other location. In addition, the oil contains a large proportion of gas, and is rich in $\mathrm{H}_{2} \mathrm{~S}$. These properties of the Tengiz reservoir are serious challenges for its exploitation, even when the latest oil production technology is used. The most dangerous accident was an explosion in 1985, which produced a 200-m-high fire column that burned for more than a year (Pala 2001). This and other accidents have led to the pollution of the surrounding soil.

Many attempts have been made worldwide to use biological systems for bioremediation of oil-polluted soil (Dua et al. 2002; Ekperusi and Aigbodion 2015; Juwarkar et al. 2010; Margesin and Schinner 2001). Among the various methods available, the combination of oil-consuming prokaryotic strains, together with plants growing in the contaminated areas, can result in the efficient cleaning of polluted soils. The microbial communities cooperate metabolically and 
exchange metabolites and end products between each other and with plants in the neighborhood (Ivanova et al. 2015; Kuiper et al. 2004; Mikolasch et al. 2016).

Till now, bacterial or fungal (Russo et al. 2019) strains have been usually applied for bioremediation of polluted areas. Soil yeasts have not been used to the same extent because they tend to have a strong endemism and there are a surprisingly high number of currently unidentified species (Yurkov 2018). On the other hand, aliphatic hydrocarbons such as $n$-alkanes of different chain lengths - an important compound group in crude oil — were used by a great variety of yeasts as the sole source of carbon and energy (Bos and de Bruyn 1973; Schauer and Schauer 1986). Approximately $20 \%$ of all yeast strains are able to use hydrocarbons. The ability to degrade aliphatic and aromatic hydrocarbons involves well-studied reactions, which are widely available among the ascomycetous (e.g., Debaryomyces, Exophiala, Lodderomyces, Metschnikowia, Pichia, or Yarrowia), the basidiomycetous (e.g., Cryptococcus, Rhodosporidium, or Sporidiobolus), and the imperfect species (e.g., Candida, Rhodotorula, or Trichosporon) (Bos and de Bruyn 1973; Middelhoven 1993; Watkinson and Morgan 1990).

The aims of the current study were to investigate the oildegrading yeast SBUG-Y 2180 taxonomically, to explore its potential to degrade oil components, and to analyze its ability to promote plant growth on oil-polluted soil.

\section{Materials and methods}

\section{Enrichment and isolation of the yeast SBUG-Y 2180}

The yeast SBUG-Y 2180 was enriched from a contaminated soil sample of the Tengiz oil field in the Atyrau region of Kazakhstan on Tengiz crude oil-containing media according to the method of Joo et al. (2008), and isolated by plating 0.1 $\mathrm{mL}$ of the enriched cultures on Sabouraud agar (Merck, Germany). Pure cultures were cultivated on malt agar slants.

\section{Identification of B1}

Physiological tests - urease test (Seeliger 1956) and 32 miniaturized assimilation tests with the API $32 \mathrm{C}$ test kit (biomerieux, Germany) - were performed using standard methods. The yeast was grown, and cells were then opened for DNA isolation as described (Mikolasch et al. 2019), method 3), and characterized by ITS gene sequence analyses (Mikolasch et al. 2019). Yeast almost full-length ITS genes were amplified using $1 \mu \mathrm{L}$ DNA extract (cell material of one

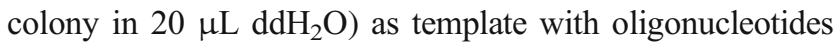
ITS1 (TCCGTAGGTGAACCTGCGG, $0.5 \mu \mathrm{M}$ ) and ITS4 (TCCTCCGCTTATTGATATGC, $0.5 \mu \mathrm{M}$ ) (White et al. 1990) as primers. Sanger sequencing was performed by
Eurofins Genomics (Germany) with ITS1 and ITS4 primers, respectively. The resulting forward and reverse sequences were assembled using the program Geneious (geneious, USA). The almost full-length ITS sequence was compared with the NCBI nr database using the blastn algorithm (Altschul et al. 1990) and the mycobank (Westerdijk Fungal Biodiversity Institute, Utrecht, The Netherlands). The best hit of the NCBI nr database and mycobank alignmentMoniliella spathulata strain CBS 241.79-was purchased from the Westerdijk Fungal Biodiversity Institute (CSB), and was treated by the same methods as the cell material of the yeast SBUG-Y 2180. The ITS sequences of the yeast SBUG-Y 2180 and the CBS Moniliella spathulata strain CBS 241.79 were compared using the blastn algorithm.

\section{Evaluation of growth in the presence of different oils}

For growth tests on different oils in liquid medium, the yeast SBUG-Y 2180 was cultivated in 500-mL flasks containing $100 \mathrm{~mL}$ of mineral salt medium for fungi (MSMF) $\mathrm{pH} 5.4$ supplemented with $1 \%$ vitamin solution (Awe et al. 2008) and with $3 \%[\mathrm{v} / \mathrm{v}]$ oil as single substrate at $30{ }^{\circ} \mathrm{C}$ and 130 rpm. After incubation, the cells were harvested, dried, and analyzed according the dry weight method (Mikolasch et al. 2015).

\section{Evaluation of growth in the presence of biphenyl and dibenzofuran}

For growth tests on the aromatic compounds biphenyl and dibenzofuran, SBUG-Y 2180 was cultivated on solid medium MSMF supplemented with $1 \%$ vitamin solution and with $20 \mathrm{mg} \mathrm{L}^{-1}$ biphenyl or dibenzofuran as single substrate at 30 ${ }^{\circ} \mathrm{C}$.

\section{Degradation experiments}

Crude oil as single substrate Cultures of SBUG-Y 2180 were shaken in 500-mL flasks with $100 \mathrm{~mL}$ MSMF medium, $1 \%$ vitamin solution, and $1 \mathrm{~mL}$ crude oil (Uzen deposit, Mangystau region, Kazakhstan) at $30^{\circ} \mathrm{C}$ and $180 \mathrm{rpm}$ for 7 , 14, and 28 days. Assays without oil or without cells or with cells and $1 \%$ glucose as sole source of carbon and energy were used as controls. All controls were treated as the transformation assays.

The data are presented as the average of four separate experiments with replicated batch cultures. These replicates did not have standard deviations more than $10 \%$.

Pristane and tetradecane as substrate mixture Cells were pregrown on MSMF plates (Awe et al. 2008; Mikolasch et al. 2019) with $0.4 \mathrm{~mL}$ tetradecane as substrate on a filter paper in the lid of the plates. Pre-cultivated cells of the isolated strain 
were shaken in 500-mL flasks containing $100 \mathrm{~mL}$ MSMF plus $0.5 \mathrm{~mL}$ tetradecane and $0.5 \mathrm{~mL}$ pristane as carbon and energy sources at $30{ }^{\circ} \mathrm{C}$ and $180 \mathrm{rpm}$ for 7 days. Assays without substrates and without cells were used as controls. Cell material from well-grown plates was used to prepare an inoculation suspension of $5 \mathrm{~mL}$. In each case, $1 \mathrm{~mL}$ of this was used to inoculate the parallel transformation assays and the control flasks. All controls were treated as the transformation assays.

Undecylcyclohexane as single substrate Cells were treated as for the degradation experiments with pristane and tetradecane, but using undecylcyclohexane $(0.1 \%(\mathrm{v} / \mathrm{v}))$ as substrate.

Biphenyl or dibenzofuran as single substrate Ten milligrams of biphenyl (BP) or dibenzofuran (DBF) dissolved in diethyl ether was added to sterile 500-mL flasks. After evaporation of the diethyl ether for $24 \mathrm{~h}, 100 \mathrm{~mL}$ of MSMF were added to each flask, and the flasks were shaken for $24 \mathrm{~h}$ at $30^{\circ} \mathrm{C}$ and $180 \mathrm{rpm}$ to achieve saturation of the compounds in the liquid medium. A cell suspension with glucose-grown cells was then added to an optical density $(A 600 \mathrm{~nm})$ of 2.00 . Cultures were incubated on a rotary shaker at $30^{\circ} \mathrm{C}$ and $180 \mathrm{rpm}$ for 7 days. Flasks with cell suspension in medium with $1 \%$ glucose as substrate, as well as flasks without substrate or flasks without cells, were used as controls. All controls were treated as the transformation assays.

\section{Identification of degradation products}

After incubation on the various substrates, whole cultures (medium, oil, and cells) were subjected to alkaline and acidic extraction, and the extracts were analyzed by GC/MS as described previously (Mikolasch et al. 2019; Mikolasch et al. 2015). Supernatants of cultures incubated on BP or DBF were analyzed by HPLC-UV/Vis (Awe et al. 2008) and after extraction (Mikolasch et al. 2019; Mikolasch et al. 2015) by GC/MS.

\section{Protein extraction and mass spectrometry analyses}

Cells were grown in triplicates for 14 days in $100 \mathrm{~mL}$ of MSMF medium with glucose or oil as carbon source. Thirty-milliliter cultures were harvested by centrifugation (10 min, $4{ }^{\circ} \mathrm{C}, 8500 \mathrm{rpm}$ ), washed three times with $2 \mathrm{~mL} \mathrm{TE}$ buffer, and finally resuspended in $1 \mathrm{~mL}$ TE buffer. Cell suspensions were transferred into screw cap tubes filled with 500 $\mu \mathrm{L}$ of lysis matrix A (MP Biomedicals) and mechanically disrupted using a FastPrep (MP Biomedicals) for $3 \times 30 \mathrm{~s}$ at $6.5 \mathrm{~m} / \mathrm{s}$ with on-ice incubation for $5 \mathrm{~min}$ between cycles. Cell debris was removed by centrifugation $\left(5 \mathrm{~min}, 4{ }^{\circ} \mathrm{C}, 13,000\right.$ $\mathrm{rpm})$, followed by a second centrifugation step $\left(30 \mathrm{~min}, 4{ }^{\circ} \mathrm{C}\right.$, 13,000). Protein concentration was determined with the Pierce BCA Protein Assay Kit (Thermo Scientific). Thirty micrograms of protein extract was separated on a 1D SDS PAGE and gel lanes cut into 5 (glucose samples) or 1 (oil samples) fractions. Tryptic in-gel digestion was described earlier (Eymann et al. 2017). Resulting peptide mixes were desalted using $\mathrm{C}_{18}$ Zip Tips (Thermo Scientific).

LC-MS/MS analyses were done on an EASY-nLC1200 coupled to an QExactive HF mass spectrometer (Thermo Fisher Scientific). Peptides were separated on a self-packed analytical column $(100 \mu \mathrm{m} \times 20 \mathrm{~cm})$ containing reversephase $\mathrm{C}_{18}$ material with an integrated emitter using an 85-min non-linear gradient from 5 to $50 \%$ buffer B $(0.1 \%$ acetic acid in acetonitrile) and a flow rate of $300 \mathrm{nl} / \mathrm{min}$. Survey scans were recorded in the Orbitrap with a resolution of 60,000 in the $\mathrm{m} / \mathrm{z}$ range of 333-1650. The 15 most-intense peaks per scan cycle were selected for fragmentation. Precursor ions were dynamically excluded from fragmentation for $30 \mathrm{~s}$; singly charged ions as well as ions with unknown charge state were rejected. Internal calibration was enabled (lock mass 445.12003).

Since the genome sequence of Moniliella spathulata is not available yet, the sequence of Moniliella sp. 'wahieum' (NCBI; assembly ASM397190v1) was used to identify proteins. The genome sequence of Moniliella sp. 'wahieum' was uploaded to the Galaxy web platform, and the public server at usegalaxy.org was used to analyze the sequence (Afgan et al. 2018). Gene prediction and translation into protein sequences were done using Augustus (Galaxy version 3.3.3) (Stanke et al. 2008). Functional annotation of predicted proteins was done using eggNOG-mapper (v2.0.0) (Huerta-Cepas et al. 2017; HuertaCepas et al. 2019). Database searching and quantification were performed using MaxQuant software (v6.1.10.43) (Cox and Mann 2008). MS and MS/MS spectra were searched against the Moniliella sp. 'wahieum' database (29,737 entries) using the following parameters: protease trypsin, two missed cleavages allowed, variable modification methionine oxidation, precursor ion mass tolerance $20 \mathrm{ppm}$, and fragment ion mass tolerance 0.5 Da. Mass spectrometry proteomics data have been deposited to the ProteomeXchange Consortium via the PRIDE partner repository (Perez-Riverol et al. 2019) with the dataset identifier PXD022543.

\section{Microbial inoculation of barley seeds by the yeast SBUG-Y 2180}

The ability of the yeast SBUG-Y 2180 to support the growth of barley on oil-contaminated soil was tested by the barley seed inoculation method (Mikolasch et al. 2015) using an incubation temperature of $28^{\circ} \mathrm{C}$ for 7 days.

\section{Results}

\section{Identification of the yeast SBUG-Y 2180}

The yeast SBUG-Y 2180 was characterized by colony appearance and cell morphology; by urease test with Christensen's 
medium; by sugar, cycloheximide, and glucosamine assimilation tests with the API $32 \mathrm{C}$ test kit; and by ITS gene sequence analyses. The isolated strain SBUG-Y 2180 produced large olive pigmented colonies with a diffuse border and a "hill" in the middle. When grown on malt agar plates, yeast-like cells with multilateral budding (Fig. 1a), hyphae with existing acropetal sprouting blastokonidia (Fig. 1b), and arthroconidia (Fig. 1c) were observed, as described for Moniliella spathulata (Kurtzman et al. 2011; Rosa et al. 2009). Formation of chlamydospores was not observed.

A positive urease test identifies the yeast as a basidiomycete. Furthermore, comparison of the SBUG-Y 2180 ITS gene sequence analyses with the NCBI nr database and the mycobank showed the highest sequence identity with Moniliella spathulata CBS 241.79 (Supplementary Table S1 and S2). When cells of this strain, obtained from the CSB strain collection, were treated by the same methods as the yeast SBUG-Y 2180 cells, they yielded similar results (Supplementary Table S3 and S4). Sequences of SBUG-Y 2180 cells and CBS 241.79 cells were compared using the blastn algorithm and showed sequence identity (100\%) using the ITS1 sequences and sequence similarity of $99.65 \%$ using the assembled ITS sequences (Supplementary Table S5 and S6). Furthermore both, CBS 241.79, which is the type sample defining the species Moniliella spathulata (Kurtzman et al. 2011), and SBUG-Y 2180 were used for assimilation tests (sugars, cycloheximide and glucosamines) with the API 32 $\mathrm{C}$ test kit. The results of all 32 miniaturized assimilation tests
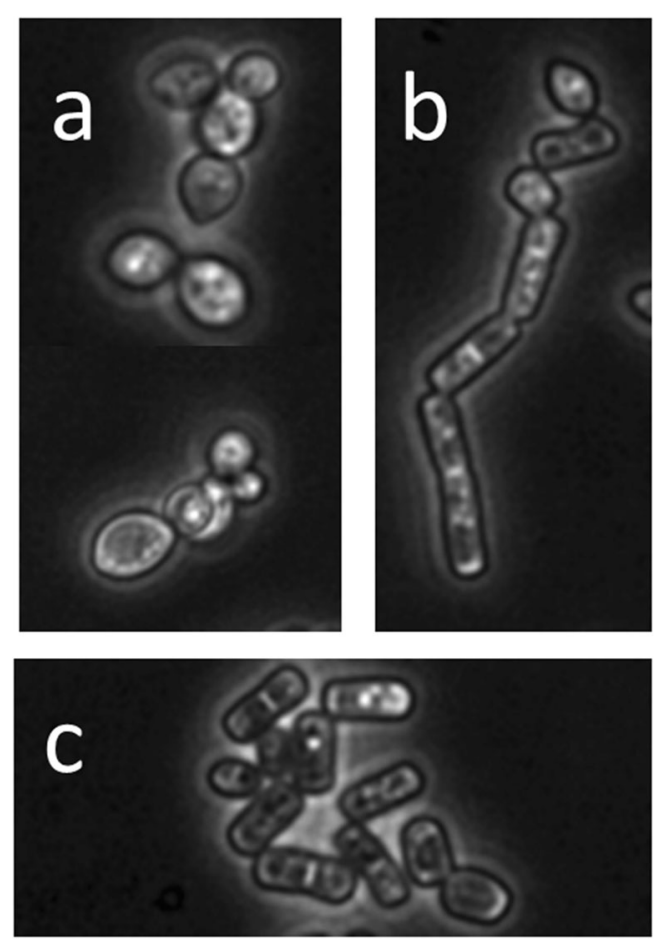

Fig. 1 a Yeast-like cells with multilateral budding, b hyphae with acropetal sprouting blastokonidia, c arthroconidia of the yeast SBUG-Y 2180; 40-fold microscopic magnification of SBUG-Y 2180 were the same as for CBS 241.79 material (Supplementary Table S7), though there were three differences to the data given in the original description (Kurtzman et al. 2011). The isolated and identified yeast SBUG-Y 2180 was deposited at the strain collection of the Department of Biology of the University Greifswald (SBUG) and named Moniliella spathulata SBUG-Y 2180 (B1). The ITS sequence was deposited in GenBank: Moniliella spathulata SBUG-Y 2180 (B1) Accession No. MT003285.

\section{Growth characteristics and crude oil consumption of Moniliella spathulata SBUG-Y 2180}

Different types of oil were used by M. spathulata SBUG-Y 2180 as the sole source of carbon and energy. The dry weight increased during cultivation in the mineral salt medium on crude oil, diesel fuel, and fuel oil for 6 days, and continued to increase during cultivation for a further 4 days (Table 1). After 10 days, M. spathulata SBUG-Y 2180 had grown well on crude oil with $72 \%$ of the growth on Sabouraud medium, whereas the growth on diesel fuel and fuel oil was much reduced, to $21 \%$ and $36 \%$, respectively.

As crude oil was the best substrate for growth, M. spathulata SBUG-Y 2180 was incubated with this oil as the sole carbon source, for a detailed investigation of the consumption of different oil components. After 7, 14, and 28 days of cultivation, whole cultures were extracted and residues were dissolved and analyzed by GC/MS (Supplementary Table S8).

The volatile $n$-alkanes with $\mathrm{C}_{9}-\mathrm{C}_{12}$ chain length and $n$ alkylcyclohexanes with chain length from $\mathrm{C}_{2}-\mathrm{C}_{4}$ evaporated completely or in part during the incubation process and could therefore not be analyzed by GC/MS (Mikolasch et al. 2015).

The other $n$-alkanes with chain length from $\mathrm{C}_{12}$ to $\mathrm{C}_{32}$ were completely degraded within 7 days of incubation. Most of the other oil components detectable by GC/MS such as alkylcyclohexanes, branched-chain alkanes, and aromatics were not fully degraded, even after 28 days. However, most of the $n$-alkylcyclohexanes, the branched-chain alkanes, the

Table 1 Growth experiments with M. spathulata SBUG-Y 2180 on 3\% $[\mathrm{v} / \mathrm{v}]$ of different oils after cultivation for 6 and 10 days and controls

Dry weight after growth on different substrates $\left[\mathrm{g} \mathrm{L}^{-1}\right]$

\begin{tabular}{lll}
\hline Substrate & 6 days & 10 days \\
\hline Crude oil & $5.6(0.054)^{\mathrm{a}}$ & $6.9(0.034)$ \\
Diesel fuel & $2.8(0.005)$ & $3.5(0.033)$ \\
Fuel oil & $1.4(0.008)$ & $2.0(0.005)$ \\
Sabouraud medium & $8.3(0.087)$ & $9.6(0.217)$
\end{tabular}

Dry weight of innoculum $0.03(0.001)\left[\mathrm{g} \mathrm{L}^{-1}\right]$

\footnotetext{
${ }^{\mathrm{a}}$ Standard deviation
} 
alkylmono- and diaromatics, and the alkylnaphthalenes were transformed to varying degrees during incubation and even aromatics without alkyl side chains like biphenyl and naphthalene were degraded by $50 \%$ and $100 \%$, respectively.

To verify the transforming potential and to characterize the degradation pathways of the crude oil components, cultures of M. spathulata SBUG-Y 2180 grown on oil were extracted at pH 2 and extracts were methylated using diazomethane and analyzed by GC/MS. A large number of acidic products were identified by comparison with standard compounds or with the spectral library of the National Institute of Standard Technology (NIST08; overview Table 2; mass spectrum data Supplementary Tables S9-S14). Sixteen different $n$-alkyl- and branched-chain alkyl-substituted monocarboxylic acids (M1M16), $8 n$-alkyl- and branched-chain alkyl-substituted dicarboxylic acids (M17-M24), 5 cyclohexylalkanoic acids (M25M29), 3 cyclopentylalkanoic acids (M30-M32), 14 phenylalkanoic acids (M33-M46), 3 naphthylalkanoic acids (M47-M49), and 2 biphenylalkanoic acids (M50 and M51) were detected. None of these were present in the original oil sample. In summary, 51 different acidic products were identified as transformation products of oil components produced by M. spathulata SBUG-Y 2180 during incubation on crude oil. In control measurements of the assays with glucose as sole source of carbon and with crude oil without cells, no acidic products were detected.

More than 150 different components of crude oil can be converted by M. spathulata SBUG-Y 2180. Furthermore, the oil components pristane, biphenyl, and dibenzofuran, compounds that are otherwise difficult to metabolize, were also utilized as sole sources of carbon and energy in degradation experiments with M. spathulata SBUG-Y 2180.

\section{Biodegradation of pristane}

Pristane and tetradecane were used as a substrate mixture to induce the alkane-degrading enzymes necessary for the biodegradation of pristane. After 14 days, five acidic transformation products of pristane were detected - a branched-chain alkyl-substituted monocarboxylic acid (pristanic acid MP4) and four branched-chain alkyl-substituted dicarboxylic acids (MP1, MP2, MP3, and MP5; Supplementary Table S15).

\section{Consumption of biphenyl and dibenzofuran}

BP or DBF were used as single sources of carbon and energy in liquid MSMF over a period of 14 days (Table 3). M. spathulata SBUG-Y 2180 was able to grow on, and to transform, both substrates. The monohydroxylated biphenyls 3- and 4-hydroxybiphenyl and all possible monohydroxylated dibenzofurans 1-, 2-, 3-, and 4-hydroxydibenzofuran were identified (Supplementary Table S16). Ring cleavage products were not detected.

\section{Transformation of phenylalkanes}

Undecylcyclohexane was used as a single substrate and as a model for phenylalkane transformation by $M$. spathulata SBUG-Y 2180. The aim of these experiments was to determine whether the cyclohexylalkanoic acids cyclohexanecarboxylic acid M25, 1-cyclohexene-1-carboxylic acid M27, and cyclohexylacetic acid M28 (Supplementary Table S11) were end products of the transformation of the phenylalkanes of crude oil, or whether they were metabolized further. After 14 days of incubation, five acidic transformation products of undecylcyclohexane were identified. In addition to the cyclohexylalkanoic acids M25, M27, and M28 (now named $\mathrm{MC}_{6} \mathrm{C}_{11} 1, \mathrm{MC}_{6} \mathrm{C}_{11} 3$, and $\mathrm{MC}_{6} \mathrm{C}_{11} 4$ in Supplementary Table S17), two aromatic acids - benzoic acid $\mathrm{MC}_{6} \mathrm{C}_{11} 2$ and phenylacetic acid $\mathrm{MC}_{6} \mathrm{C}_{11} 5$ - were detected.

\section{Identification of candidate enzymes involved in transformation of crude oil compounds}

Both M. spathulata SBUG-Y 2180 and the CBS M. spathulata strain CBS 241 were grown in the presence of glucose and crude oil, respectively. Only for glucose-grown cells was protein extraction successful; therefore, we were not able to identify enzymes that might be specifically synthesized in the presence of oil. Tryptic peptides of glucose-grown cells were analyzed by LC-MS/MS to identify possible candidates that might be involved in the degradation/transformation of crude oil. We could detect 24 proteins that might be associated with the transformation of oil according to their functional prediction (Table 4). This includes enzymes involved in aromatic ring cleavage (RSEE01000002.1.g1287), degradation of aliphatic carbohydrates (e.g., RSEE01000006.1.g3392, RSEE01000006.1.g3393, RSEE01000053.1.g18113, RSEE01000008.1.g4308, RSEE01000073.1.g21446, RSEE01000022.1.g10034, RSEE01000031.1.g12774, RSEE01000079.1.g22204, RSEE01000076.1.g21850, RSEE01000029.1.g12222), or initial hydroxylations (RSEE01000002.1.g906).

\section{Influence of yeast inoculation of barley seeds on the plant development}

All the described experiments showed that M. spathulata SBUG-Y 2180 is a highly potent yeast for crude oil degradation. In order to show that this yeast not only theoretically has a high degradation potential but actually has an influence on the growth of plants that are used for soil remediation of oilcontaminated areas, barley seeds and $M$. spathulata SBUG-Y 2180 cells were used together in soil experiments.

Barley seeds were inoculated with $M$. spathulata SBUG-Y 2180 at a cell density of $25 \times 10^{6} \mathrm{CFU} / \mathrm{g}$ sand, and sown in oilcontaining sand ( $2 \%$ oil). Plants were grown for 7 days and the 
Table 2 Aliphatic and aromatic parent components of crude oil and the acids formed by M. spathulata SBUG-Y 2180 detected by GC/MS during growth on crude oil

\begin{tabular}{|c|c|c|c|}
\hline \multicolumn{2}{|l|}{ Detected oil components } & \multicolumn{2}{|c|}{ Detected transformation products ${ }^{\mathrm{a}}$} \\
\hline Name & Transformation extent $\mathrm{t}^{\mathrm{b}}$ & Number & Name \\
\hline \multicolumn{4}{|l|}{$n$-Alkanes (23 detected compounds) } \\
\hline Decane to dotriacontane & Total & 3 & $\begin{array}{l}\text { Heptanoic acid M7 } \\
\text { Hexanedioic acid M19 } \\
\text { Decanedioic acid M24 }\end{array}$ \\
\hline \multicolumn{4}{|l|}{ Branched-chain alkanes (numerous) } \\
\hline Monoethyl-substituted alkanes & Total & 2 & $\begin{array}{l}\text { 2-Ethyl-hexanoic acid M10 } \\
\text { 2-Ethylidene-propanedioic acid M17 }\end{array}$ \\
\hline $\begin{array}{l}\text { Monomethyl-substituted alkanes } \\
\text { Polymethyl-substituted alkanes } \\
\text { e.g., 2,6,10-Trimethyl-dodecane } \\
\text { 2,6,10-Trimethyl-pentadecane } \\
\text { Pristane (2,6,10,14-tetramethylpentadecane) } \\
\text { 2,6,10,14-Tetramethylhexadecane }\end{array}$ & $\begin{array}{l}\text { Total } \\
\text { Partial }\end{array}$ & $13^{\mathrm{d}}$ & $\begin{array}{l}\text { 3-Methyl-but-2-enoic acid M1 } \\
\text { 3-Hydroxy-3-methyl-butanoic acid M3 } \\
\text { 3-Methyl-pentanoic acid M4 } \\
\text { 3-Methyl-pent-2-enoic acid M5 } \\
\text { 3-Methyl-2-oxo-pentanoic acid M6 } \\
\text { 2-Hydroxy-3-methyl-but-2-enoic acid M8 } \\
\text { 3-Methyl-hex-2-enoic acid M9 } \\
\text { 2-Hydroxy-4-methyl-pent-2-enoic acid M11 } \\
\text { 3-Methyl-pentanedioic acid M18 } \\
\text { 2-Methyl-hexanedioic acid M20 } \\
\text { 3-Methyl-hexanedioic acid M21 } \\
\text { 3-Methyl-heptanedioic acid M22 } \\
\text { 4-Methyl-heptanedioic acid M23 }\end{array}$ \\
\hline & & $5^{e)}$ & $\begin{array}{l}\text { 2,3-Dimethyl-butanoic acid M2 } \\
\text { Dimethyl-octanoic acids M13, M14, } \\
\text { M15, M16 }\end{array}$ \\
\hline \multicolumn{4}{|l|}{ Alkylcyclohexanes } \\
\hline \multicolumn{4}{|l|}{$\begin{array}{l}n \text {-Alkylcyclohexanes (23 detected } \\
\text { compounds) }\end{array}$} \\
\hline $\begin{array}{l}\text { Ethylcyclohexane to } \\
\text { octadecylcyclohexane }\end{array}$ & Partial & 4 & $\begin{array}{l}\text { Cyclohexanecarboxylic acid M25 } \\
\text { 1-Cyclohexene-1-carboxylic acid M27 } \\
\text { Cyclohexylacetic acid M28 } \\
\text { Cyclohexylpropanoic acid M29 }\end{array}$ \\
\hline \multicolumn{4}{|l|}{$\begin{array}{l}\text { n-Alkyl-methylcyclohexanes ( } 40 \\
\text { detected compounds) }\end{array}$} \\
\hline Methyl-substituted & Total & 1 & 4-Methyl-cyclohexane-1-carboxylic acid M26 \\
\hline \multicolumn{4}{|l|}{ Alkylcyclopentanes } \\
\hline \multicolumn{4}{|l|}{$\begin{array}{l}\text { n-Alkylcyclopentanes } \\
\text { (compounds detected in traces) }\end{array}$} \\
\hline$n$-Alkylcyclopentanes & Total & 2 & $\begin{array}{l}\text { Cyclopentanecarboxylic acid M30 } \\
\text { 1-Cyclopentene-1-carboxylic acid M31 }\end{array}$ \\
\hline \multicolumn{4}{|l|}{$\begin{array}{l}\text { n-Alkyl-methylcyclopentanes } \\
\text { (compounds detected in traces) }\end{array}$} \\
\hline Methyl-substituted & Total & 1 & 3-Methyl-cyclopentane-1-carboxylic acid M32 \\
\hline \multicolumn{4}{|l|}{$\begin{array}{l}\text { Alkylbenzenes ( } 28 \text { well-detected, and traces } \\
\text { of longer-chain compounds) }\end{array}$} \\
\hline n-Alkyl-substituted benzenes & Partial & 5 & $\begin{array}{l}\text { Benzoic acid M33 } \\
\text { Phenylacetic acid M34 } \\
\text { 2-Hydroxy-, 4-hydroxy-benzoic } \\
\text { acid M35, M44 } \\
\text { 3,4-Dihydroxy-benzoic acid M46 }\end{array}$ \\
\hline Poly- $n$-alkyl-substituted benzenes & Total & 6 & $\begin{array}{l}\text { 3-Methyl, 4-methyl-benzoic acid M36, } \\
\text { M37 } \\
\text { 4-Methyl-phenylacetic acid M38 } \\
\text { 2,4-Dimethyl, 3,5-dimethyl-benzoic } \\
\text { acid M40, M42 } \\
\text { 4-Ethyl-benzoic acid M41 }\end{array}$ \\
\hline
\end{tabular}


Table 2 (continued)

Detected oil components

$\begin{array}{ll}\text { Name } & \text { Transformation extent } \\ \text { Branched-chain-alkyl-substituted benzenes } & \text { Total }\end{array}$

Naphthalenes (4 well-detected, and traces of longer-chain compounds)

Naphthalene

n-Alkyl-substituted naphthalenes

Biphenyls ( 3 well-detected, and traces of longer-chain compounds)

Biphenyl
$n$-Alkyl-substituted biphenyls

Detected transformation products ${ }^{\mathrm{a}}$

\begin{tabular}{ll}
\hline Number & Name \\
3 & 2-Phenylpropionic acid M39 \\
& 2-Phenylbutyric acid M43 \\
& 3-Phenylbutyric acid M45
\end{tabular}

\section{$-$}

3

1- and 2-naphthalenecarboxylic acid M47, M48

1-Naphthaleneacetic acid M49

${ }^{\mathrm{a}}$ See structures and analytical data of the acids formed in Supplementary Tables S9-S14

${ }^{\mathrm{b}}$ See the amount of transformation [\%] after 7, 14, and 28 days in Supplementary Table S8

${ }^{\mathrm{c}}$ Names of acidic products with numbers according to increasing retention times in the GC elution profile, Supplementary Tables S9-S14

${ }^{\mathrm{d}}$ Possible detected transformation products of mono- and polymethyl-substituted alkanes

${ }^{\mathrm{e}}$ Possible detected transformation products of polymethyl-substituted alkanes only

number of CFU of $M$. spathulata SBUG-Y 2180, the lengths of shoots and roots, and the rate of germination were then measured (Fig. 2). A considerable protective effect on barley

Table 3 Growth of M. spathulata SBUG-Y 2180 on biphenyl and dibenzofuran and metabolites formed by M. spathulata SBUG-Y 2180 during transformation of biphenyl and dibenzofuran

\begin{tabular}{|c|c|c|c|}
\hline \multicolumn{4}{|l|}{ Biphenyl } \\
\hline \multicolumn{2}{|c|}{ Biphenyl growth } & \multicolumn{2}{|c|}{ Control growth on glucose } \\
\hline 7 days & 14 days & 7 days & 14 days \\
\hline++ & +++ & +++ & +++ \\
\hline \multicolumn{4}{|c|}{ Biphenyl metabolites after 14 days } \\
\hline $\begin{array}{l}\text { 4-OH-BP } \\
\text { (MBP1) } \\
\text { d }\end{array}$ & $\begin{array}{l}\text { 3-OH-BP } \\
\text { (MBP2) } \\
d\end{array}$ & \multicolumn{2}{|l|}{ 2-OH-BP } \\
\hline \multicolumn{4}{|c|}{ Dibenzofuran } \\
\hline \multicolumn{2}{|c|}{ Dibenzofuran growth } & \multicolumn{2}{|c|}{ Control growth on glucose } \\
\hline 7 days & 14 days & 7 days & 14 days \\
\hline+ & ++ & +++ & +++ \\
\hline \multicolumn{4}{|c|}{ Dibenzofuran metabolites after 14 days } \\
\hline $\begin{array}{l}\text { 4-OH-DBF } \\
\text { (MDBF1) }\end{array}$ & $\begin{array}{l}\text { 3-OH-DBF } \\
\text { (MDBF2) }\end{array}$ & $\begin{array}{l}\text { 2-OH-DBF } \\
\text { (MDBF3) }\end{array}$ & $\begin{array}{l}\text { 1-OH-DBF } \\
\text { (MDBF4) }\end{array}$ \\
\hline d & d & $\mathrm{d}$ & $\mathrm{d}$ \\
\hline
\end{tabular}

++ good growth, +++ very good growth, $d$ detected and identified using HPLC and/or GC/MS (Supplementary Table S16), nd not detected using HPLC and/or GC/MS (Supplementary Table S16) was observed in the growth assay inoculated with M. spathulata SBUG-Y 2180. This treatment of seeds stimulated the growth of barley seedlings in oil-contaminated sand, increasing the growth of shoots by $44 \%$ and of roots by $20 \%$ compared with the growth in oil-containing sand without inoculation. The $\mathrm{P}(\mathrm{T}<-\mathrm{t})$ values are $1.06 \mathrm{E}-10$ and $2.16 \mathrm{E}-06$, respectively, and they support the hypothesis of significant growth increase by the inoculation of seeds with M. spathulata SBUG-Y 2180 in oil-containing sand. It should be emphasized that the root growth of barley seedlings inoculated with M. spathulata SBUG-Y 2180 in pristine sand is also $41 \%$ lower than in assays without inoculation and pristine sand. Nevertheless, there is better root growth in oilcontaminated sand with the yeast than without the yeast inoculation. Furthermore, the rate of seed germination increased by $15 \%$ and was only $5 \%$ lower than that of barley growth without oil. Parallel experiments with inoculation of barley seeds with M. spathulata SBUG-Y 2180 and their growth in sand without oil and experiments without barley were conducted. The inoculation of seeds with the yeast had no positive effect on growth of barley without oil. Furthermore, the number of CFU increased by a factor of 600 in the control assay with oil, but without plants. In comparison, the number of CFU of the assay with barley, M. spathulata SBUG-Y 2180, and oil was $19 \%$ higher and that of the assay with barley and M. spathulata SBUG-Y 2180 and without oil was $79 \%$ higher than that of the control assay. The $\mathrm{P}(\mathrm{T}<-\mathrm{t})$ values are $2.65 \mathrm{E}$ 
Table 4 Proteins identified by LC-MS/MS with possible involvement in oil degradation in M. spathulata CBS 241 and SBUG-Y 2180

\begin{tabular}{|c|c|c|c|}
\hline Protein accession ${ }^{\mathrm{a}}$ & Description $^{\mathrm{b}}$ & ID CBS $241^{\mathrm{c}}$ & $\begin{array}{l}\text { ID SBUG-Y } \\
2180^{c}\end{array}$ \\
\hline RSEE01000002.1.g1287 & $\begin{array}{l}\text { Catalyzes the oxidative ring opening of } \\
\text { 3-hydroxyanthranilate to 2-amino- } \\
\text { 3-carboxymuconate semialdehyde, } \\
\text { which spontaneously cyclizes to quinolinate }\end{array}$ & $\mathrm{X}$ & $\mathrm{X}$ \\
\hline RSEE01000002.1.g906 & monooxygenase & $\mathrm{X}^{*}$ & $\mathrm{X}$ \\
\hline RSEE01000006.1.g3392 & Aldehyde dehydrogenase family & $\mathrm{X}$ & $\mathrm{X}$ \\
\hline RSEE01000006.1.g3393 & Aldehyde dehydrogenase family & $\mathrm{X}$ & $\mathrm{X}$ \\
\hline RSEE01000008.1.g4308 & Phytanoyl-CoA dioxygenase (PhyH) & $\mathrm{X}$ & $\mathrm{X}$ \\
\hline RSEE01000022.1.g10034 & Acyl-CoA dehydrogenase, C-terminal domain & $\mathrm{X}$ & $\mathrm{X}$ \\
\hline RSEE01000025.1.g11051 & Alcohol dehydrogenase GroES-like domain & $\mathrm{X}$ & $\mathrm{X}$ \\
\hline RSEE01000025.1.g11099 & Belongs to the acyl-CoA oxidase family & $\mathrm{X}^{*}$ & $\mathrm{X}$ \\
\hline RSEE01000029.1.g12222 & Belongs to the thiolase family & $\mathrm{X}$ & $\mathrm{X}$ \\
\hline RSEE01000031.1.g12774 & Alpha-beta-hydrolase & $\mathrm{X}$ & $\mathrm{X}$ \\
\hline RSEE01000034.1.g13603 & Dyp-type peroxidase family & $\mathrm{X}$ & $\mathrm{X}^{*}$ \\
\hline RSEE01000036.1.g14415 & Belongs to the aldehyde dehydrogenase family & $\mathrm{X}$ & $\mathrm{X}$ \\
\hline RSEE01000047.1.g16882 & Belongs to the aldehyde dehydrogenase family & $\mathrm{X}^{*}$ & - \\
\hline RSEE01000052.1.g18003 & Aldehyde dehydrogenase family & $\mathrm{X}$ & $\mathrm{X}$ \\
\hline RSEE01000053.1.g18113 & Belongs to the thiolase family & - & $\mathrm{X}^{*}$ \\
\hline RSEE01000056.1.g18812 & Belongs to the aldehyde dehydrogenase family & - & $\mathrm{X}^{*}$ \\
\hline RSEE01000059.1.g19195 & $\begin{array}{l}\text { Catalyzes a 2-step reaction, involving the } \\
\text { ATP-dependent carboxylation of the covalently } \\
\text { attached biotin in the first step and the transfer of } \\
\text { the carboxyl group to pyruvate in the second }\end{array}$ & $\mathrm{X}$ & $\mathrm{X}$ \\
\hline RSEE01000073.1.g21446 & $\begin{array}{l}\text { D-Isomer specific 2-hydroxyacid dehydrogenase, } \\
\text { catalytic domain }\end{array}$ & $\mathrm{X}$ & $\mathrm{X}$ \\
\hline RSEE01000075.1.g21656 & $\begin{array}{l}\text { D-Isomer specific 2-hydroxyacid dehydrogenase, } \\
\text { catalytic domain }\end{array}$ & $\mathrm{X}$ & $\mathrm{X}$ \\
\hline RSEE01000076.1.g21850 & $\begin{array}{l}\text { 3-Hydroxyacyl-CoA dehydrogenase, NAD } \\
\text { binding domain }\end{array}$ & $\mathrm{X}$ & $\mathrm{X}$ \\
\hline RSEE01000079.1.g22204 & Alpha-beta-hydrolase & $\mathrm{X}$ & $\mathrm{X}$ \\
\hline RSEE01000108.1.g25431 & Belongs to the peroxidase family & $\mathrm{X}$ & $\mathrm{X}$ \\
\hline RSEE01000159.1.g28641 & Belongs to the aldehyde dehydrogenase family & $\mathrm{X}$ & $\mathrm{X}$ \\
\hline RSEE01000187.1.g29162 & Peroxidase & $\mathrm{X}$ & $X$ \\
\hline
\end{tabular}

${ }^{a}$ Protein accessions were provided by the Galaxy web platform (see MM for details)

${ }^{\mathrm{b}}$ Functional prediction is based on eggNOG-mapper

${ }^{\mathrm{c}}$ Enzymes that were identified in the respective strain with at least two peptides are marked with "X"; additionally, if a protein was only identified in one out of three biological replicates, it is marked with "*" "

-07 and $4.98 \mathrm{E}-13$, respectively, and they show significantly higher CFUs and indicate that the presence of barley increases the development of the yeast. All results together show that M. spathulata SBUG-Y 2180 promotes growth and germination of barley in the oil-contaminated sand and barley also positively influences the development of $M$. spathulata SBUG-Y 2180.

\section{Discussion}

The yeast strain SBUG-Y 2180 was isolated from oilcontaminated soil of the Tengiz oil field in the Atyrau region of Kazakhstan. This yeast was identified as the basidiomycete Moniliella spathulata. Although this species has not been previously isolated from oilcontaminated areas, other species of Moniliella have been isolated from such oil-rich habitats (Ching et al. 2016; Ye et al. 2017). M. spathulata was formerly known as Trichosporonoides spathulata, but in 2009, all species of Trichosporonoides were transferred to the genus Moniliella because both genera are members of a single monophyletic clade (Rosa et al. 2009). T. spathulata has been isolated from the waste of palm oil mills and biodiesel plants (Kitcha and Cheirsilp 2013), which can contain similar hydrocarbons as oil-contaminated habitats. 
Fig. 2 Influence of $M$. spathulata SBUG-Y 2180 inoculation of barley seeds on the plant development in oil-containing sand after 7 days. Number of yeast cells of M. spathulata SBUG-Y 2180 at the beginning: $25 \times 10^{6} \mathrm{CFU} / \mathrm{g}$ sand

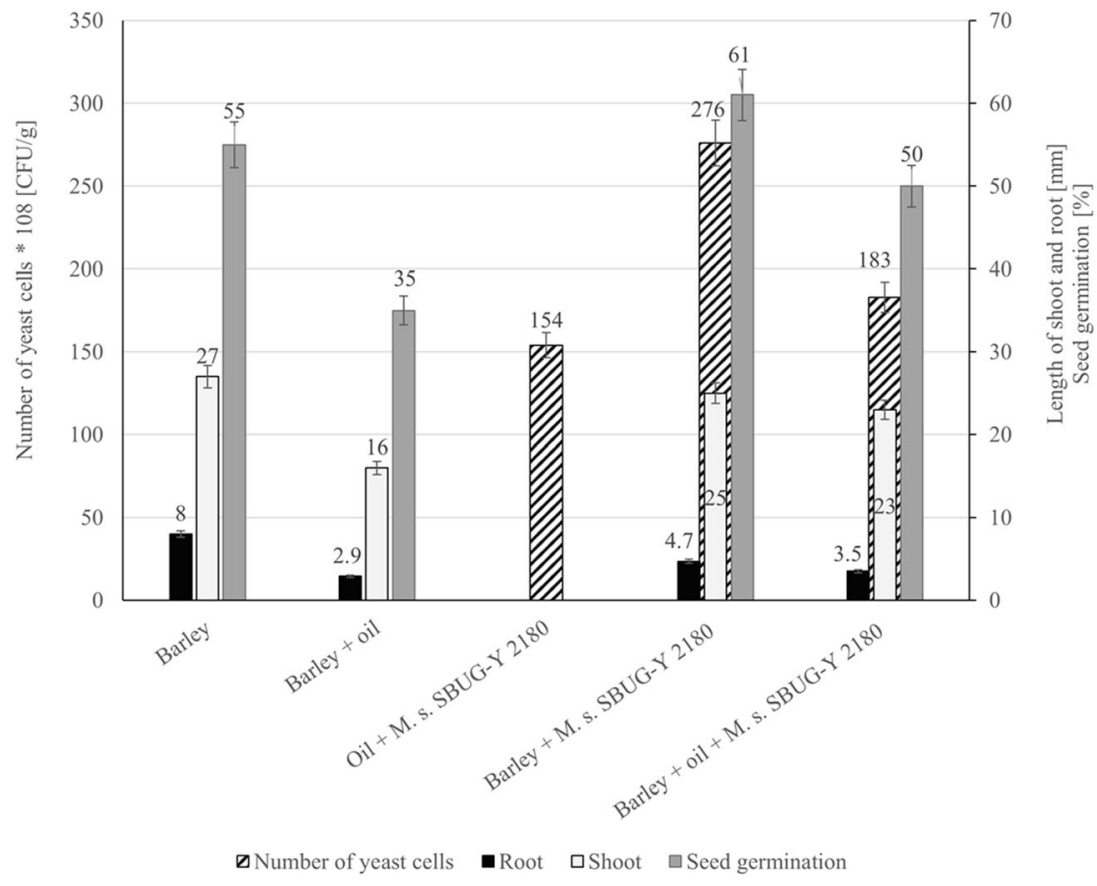

To study the spectrum of oil components utilized by the strain, we used crude oil with a low content of resins and asphaltenes, on which M. spathulata SBUG-Y 2180 grew well. Diesel fuel and fuel oil have a higher content of sulfur, resins, asphaltenes, and other high molecular weight components than crude oil and are consequently more difficult to degrade (Gailiūtè et al. 2011; Khorasani et al. 2013). In line with this, M. spathulata SBUG-Y 2180 grew very poorly on medium with fuel oil and poorly on diesel fuel. In addition to growth on crude oil, M. spathulata SBUG-Y 2180 can biodegrade an unusually wide spectrum of more than 150 hydrocarbons as substrates (Supplementary Table S8). More than 51 aliphatic and aromatic acids were formed during the degradation of the oil components (Table 2). Thus, this study establishes that yeasts can have oil-degrading properties comparable to those of bacteria (Mikolasch et al. 2015; Mikolasch et al. 2016), which was also described for yeast strains of the genera Candida and Trichosporon (Farag and Soliman 2011; Gargouri et al. 2015). Proteome analyses of M. spathulata showed expression of nearly all potential enzymes necessary for the degradation of alkanes and alkyl chains of cycloaliphatic compounds via initial hydroxylation, transformation to acids, and $\beta$-oxidation: monooxygenase (moo), alcohol dehydrogenase (alcd), aldehyde dehydrogenase (aldd), acyl-CoA dehydrogenase $(\mathrm{aCd})$, alpha-beta-hydrolase (abh), 3hydroxyacyl-CoA dehydrogenase $(3 \mathrm{OHaCd})$, and thiolase (thio) (Fig. 3). M. spathulata SBUG-Y 2180 is able to transform not only easy-to-degrade $n$-alkanes and $n$-alkyl chains by these enzymes but also polymethyl-substituted alkanes like pristane and phytane (Fig. 4), which are more difficult to deal with. Given the branched-chain alkyl-substituted mono- and dicarboxylic acids MP1 to MP5 (Supplementary Table S15) detected, this yeast used the diterminal degradation pathway as described for bacteria (Mikolasch et al. 2019; Nhi-Cong et al. 2010; Nhi-Cong et al. 2009; Pirnik and McKenna 1977). Phytane is degraded by nearly the same pathway as pristane. The initial steps are also catalyzed by monooxygenase (moo), alcohol dehydrogenase (alcd), and aldehyde dehydrogenase (aldd) forming phytanic acid. Phytanic acid is transformed via $\alpha$-oxidation. The first enzyme of the $\alpha$-oxidation, the phytanoyl-CoA dioxygenase (phyCd), was detected by proteome analysis.

Previously, pristane was considered more as an inert carrier for poorly water-soluble substrates during their transformation by yeasts (Green et al. 2000). Alternatively, yeasts have been held to be members of pristane- and phytane-degrading communities of bacteria, yeasts, and fungi (Ururahy et al. 1998), though the roles of the different species in the consumption process were not further investigated.

In addition to its degradation of aliphatic hydrocarbons, M. spathulata SBUG-Y 2180 is also able to transform aromatic hydrocarbons like biphenyl and dibenzofuran (Table 3). Some enzymes that might be involved in the degradation of aromatic hydrocarbons were found by proteome analyses (Table 4): RSEE01000002.1.g906, RSEE01000002.1.g1287, RSEE01000108.1.g25431, and RSEE01000187.1.g29162. Other yeasts can also transform biphenyls and dibenzofurans. In some cases, ring cleavage products were detected, while in the majority, as with M. spathulata SBUG-Y 2180, only hydroxylated products were found (Romero et al. 2002; Schlüter et al. 2013; Sietmann et al. 2006; Sietmann et al. 2000; Zinjarde et al. 2014). However, little is currently known about 
Fig. 3 Proposed degradation pathways of $n$ -

undecylcyclohexane by M. spathulata SBUG-Y 2180.

$\mathrm{MC}_{6} \mathrm{C}_{11} 1-\mathrm{MC}_{6} \mathrm{C}_{11} 5$ metabolites identified by $\mathrm{GC} / \mathrm{MS}$ during incubation of $M$. spathulata SBUG-Y 2180 on $n$ undecylcyclohexane. M35 and M46 metabolites identified by GC/MS during growth on crude oil of M. spathulata SBUG-Y 2180 (detailed structural characterization of $\mathrm{MC}_{6} \mathrm{C}_{11} 1$ $\mathrm{MC}_{6} \mathrm{C}_{11} 5$ Supplementary Table S17, of M35 and M46 Supplementary Table S13). Enzymes detected by proteome analyses: moo, monooxygenase; alcd, alcohol dehydrogenase; aldd, aldehyde dehydrogenase; aCd, acyl-CoA dehydrogenase; abh, alpha-beta-hydrolase; 3OHaCd, 3-hydroxyacyl-CoA dehydrogenase; and thio, thiolase. Undetected intermediates in brackets. Solid arrows correspond to proven reaction steps. Dashed arrows correspond to assumed reaction steps
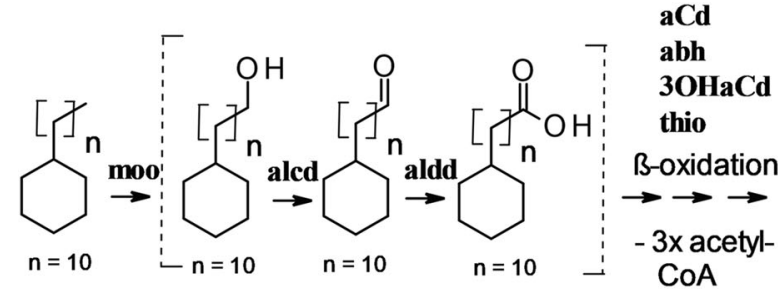

(2)

p-oxidation

aCd<smiles>O=C(O)C/C=C/CC1CCCCC1</smiles>

- propionyl- $\overrightarrow{\mathrm{C}} \mathrm{A}$

\-oxidation

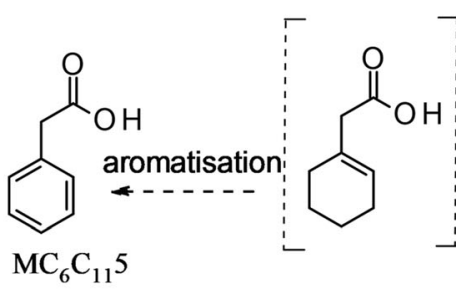

1. step
y-oxi-
dation

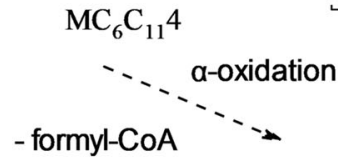

$\overbrace{\substack{\text { abheHaCd } \\ \text { thio }}}^{2 O H}$

$\downarrow$ - acetyl-CoA

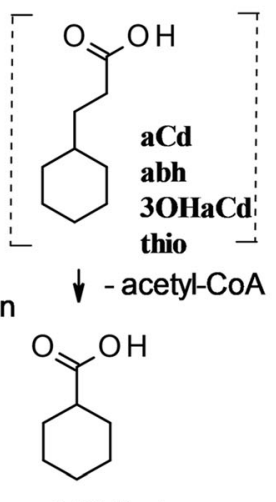<smiles>O=C(O)[C@@H](I)[14CH2][14CH2][14C](=O)O[14C](=O)c1ccc(O)c(O)c1</smiles>

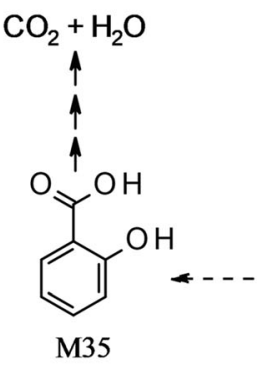

$\mathrm{MC}_{6} \mathrm{C}_{11} 1$ aCd

$\downarrow$ 1. step ß-oxidation<smiles>CC(C)(C)[Mg]</smiles><smiles>O=C(O)C1=CCCCC1</smiles>

M46

fungal degradation of alicyclic hydrocarbons, and the alicyclic fraction of oil is among the most degradation-resistant components. Undecylcyclohexane, a representative of the alicyclic fraction of oil, was transformed to five different acids by M. spathulata SBUG-Y 2180 (Fig. 3 degradation example $n$-undecylcyclohexane). The first reaction steps are the same as for the degradation of $n$-alkanes - monoterminal oxidation via an alcohol and an aldehyde intermediate to the corresponding carboxylic acid, followed by further $\beta$-oxidation (Morgan and Watkinson 1994; Ratledge 1978). A product of these transformations is cyclohexanecarboxylic acid, which was found as an intermediate in our assays and is referred to as $\mathrm{MC}_{6} \mathrm{C}_{11} 1$. Furthermore, all enzymes that might possibly catalyze the reactions of this pathway were detected by proteome analyses (Fig. 3). The degradation of the $n$-alkyl chain of $n$ alkylcyclohexanes by additional oxidation mechanisms has been previously proposed (Beam and Perry 1974; Dutta and
Harayama 2001; Rontani and Bonin 1992). Both carboxylic acid and acetic acid derivatives were identified from $n$ undecylcyclohexane, $n$-dodecylcyclohexane, $n$ heptadecylcyclohexane, $n$-octadecylcyclohexane, and $n$ nonadecylcyclohexane. The product cyclohexane acetic acid $\mathrm{MC}_{6} \mathrm{C}_{11} 4$ was also detected by $\mathrm{GC} / \mathrm{MS}$ in extracts of M. spathulata SBUG-Y 2180 cultivated on $n$ undecylcyclohexane. While Beam and Perry (1974) and Rontani and Bonin (1992) favor $\alpha$-oxidation as a minor pathway in addition to $\beta$-oxidation, Dutta and Harayama (2001) outline $\gamma$-oxidation as a further alternative pathway. Regardless of $\alpha$ - or $\gamma$-oxidation, we detected both cyclohexanecarboxylic and cyclohexane acetic acid, which indicate pathways parallel to $\beta$-oxidation. The $\gamma$-pathway does appear to be involved, since the removal of propionylCoA from acidic substances has also been described in the degradation of pristane (Fig. 4). Furthermore, we found 
Fig. 4 Proposed diterminal oxidation pathway for the degradation of pristane and phytane by $M$. spathulata SBUG-

Y 2180 (detailed structural characterization of pristane metabolites in Supplementary Table S15). Enzymes detected by proteome analyses: moo, monooxygenase; alcd, alcohol dehydrogenase; aldd, aldehyde dehydrogenase; aCd, acyl-CoA dehydrogenase; abh, alpha-betahydrolase; $3 \mathrm{OHaCd}, 3-$ hydroxyacyl-CoA

dehydrogenase; thio, thiolase; and phyCd, phytanoyl-CoA dioxygenase. Undetected intermediates in brackets

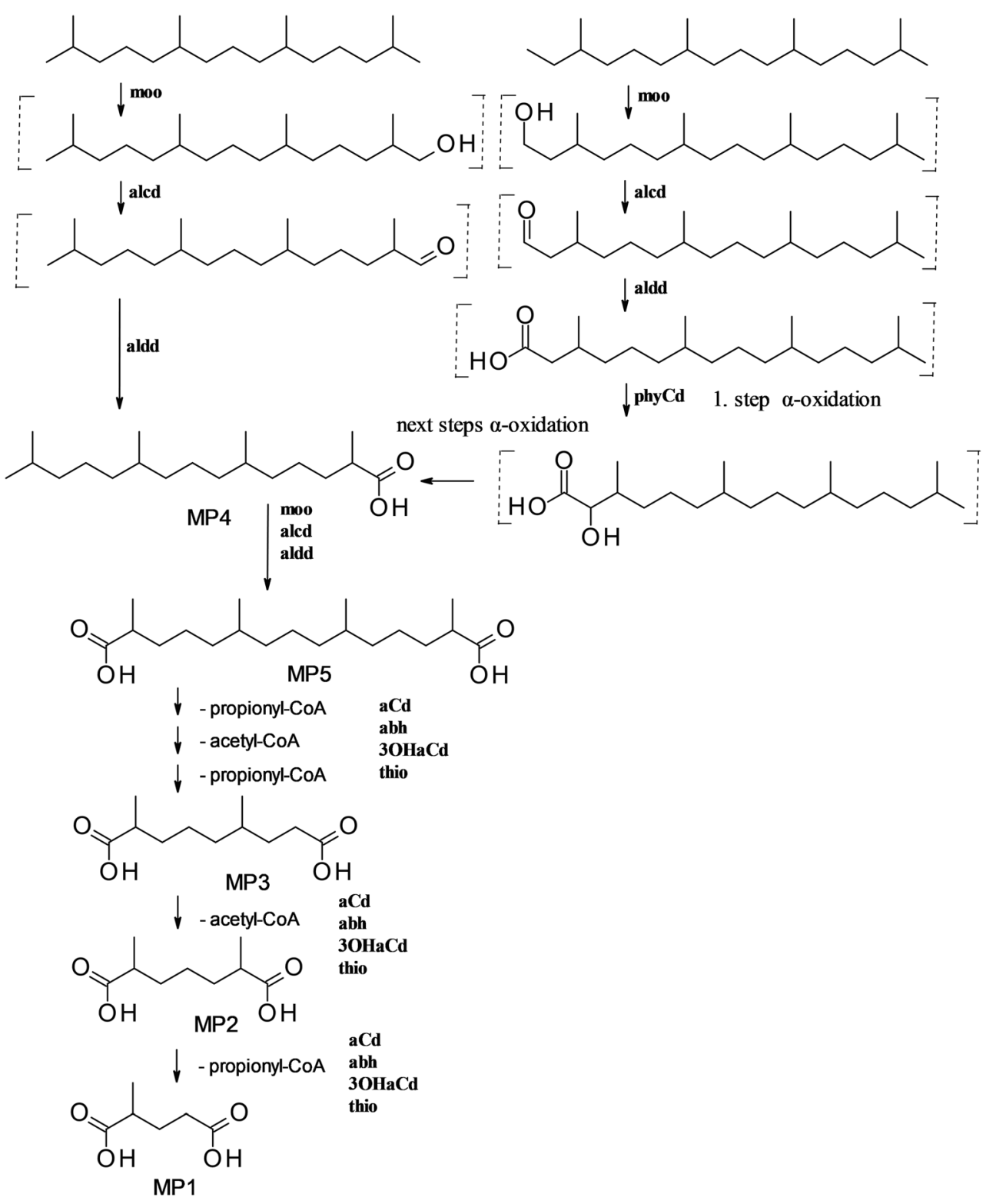

$\mathrm{MC}_{6} \mathrm{C}_{11} 2, \mathrm{MC}_{6} \mathrm{C}_{11} 3$, and $\mathrm{MC}_{6} \mathrm{C}_{11} 5$ as additional transformation products. $\mathrm{MC}_{6} \mathrm{C}_{11} 3$ can be an intermediate of further $\beta$ oxidation, as shown for the assimilation of cyclohexane acetic acid (Rontani and Bonin 1992). Alternatively, it can be a product of an aromatization process to benzoic acid (Dutta and Harayama 2001), which was also found in our assays, and is referred to as $\mathrm{MC}_{6} \mathrm{C}_{11} 2$. The question of how the phenylacetic acid $\mathrm{MC}_{6} \mathrm{C}_{11} 5$ is formed must remain open at this point, though we assume a first step of $\gamma$-oxidation followed by an aromatization such as for $\mathrm{MC}_{6} \mathrm{C}_{11} 1$. On the basis of all the analyzed transformation products, we propose pathways for catabolism of the main oil components by M. spathulata SBUG-Y 2180 (Fig. 5).

M. spathulata SBUG-Y 2180 is able to transform more than 150 compounds from 9 different groups present as major components of Kazakh crude oil. This basidiomycete yeast is able to degrade $n$-alkyl, branched-chain, aromatic, and polycyclic aromatic structures. Furthermore, the use of M. spathulata SBUG-Y 2180 in plant growth experiments resulted in improvements in germination (15\%) and in shoot (44\%) and root (20\%) growth of barley in the presence of crude oil. The $\mathrm{P}(\mathrm{T}<-\mathrm{t})$ values support the hypothesis of significant growth increase by the inoculation of seeds with M. spathulata SBUG-Y 2180 in oil-containing sand. The inoculation of barley with bacteria of the genera Gordonia and Rhodococcus or the inoculation with culture mixtures of the genera Rhodococcus and Bacillus or Rhodococcus and Sphingobacterium promoted the growth of barley in the same way as M. spathulata SBUG-Y 2180 (Mikolasch et al. 2015; Mikolasch et al. 2016), in which the effects to the shoot 


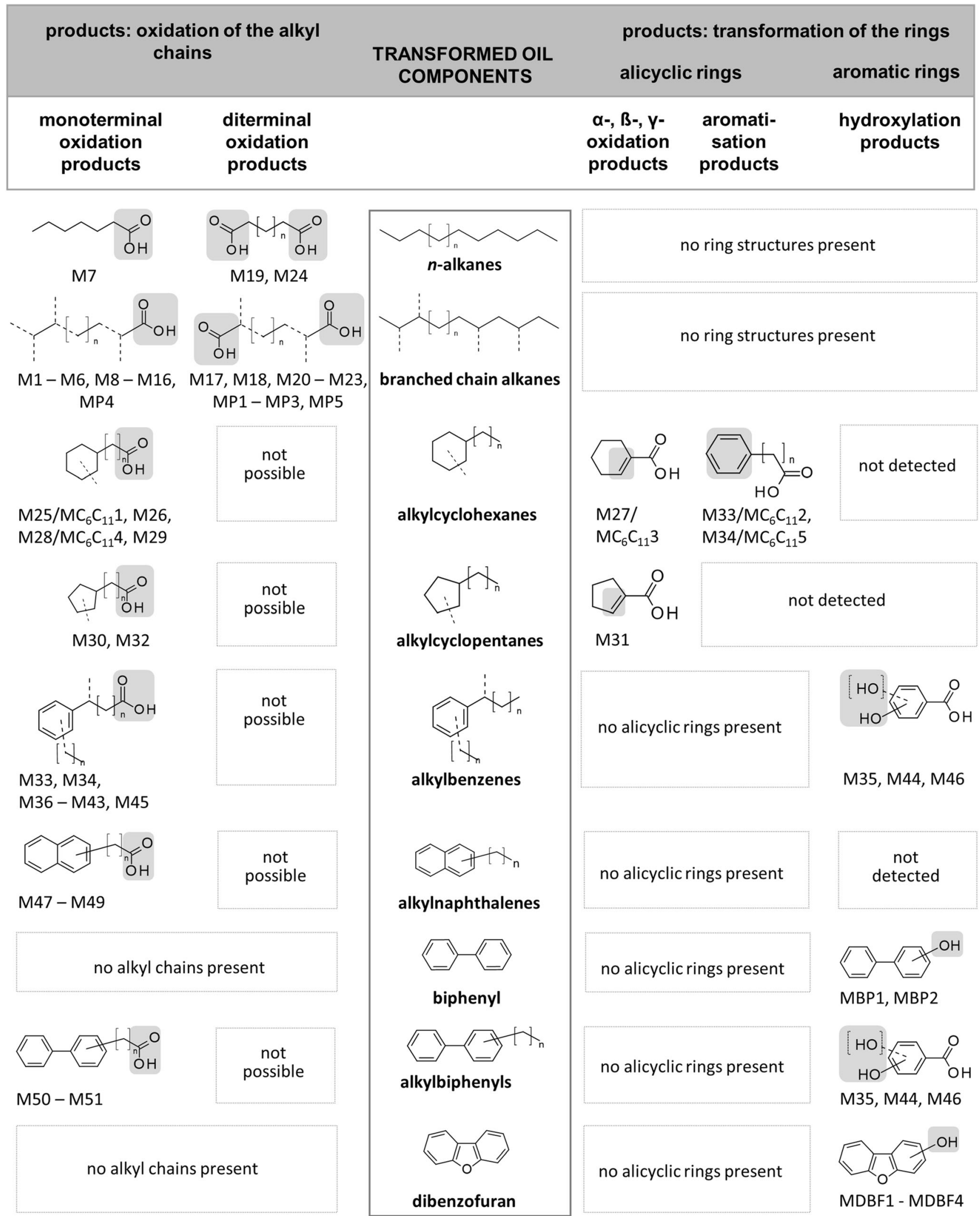

Fig. 5 Overview of transformation pathways for the main oil components by M. spathulata SBUG-Y 2180 
growth are comparable, but the root growth promotion of M. spathulata SBUG-Y 2180 is less than by the named bacteria.

In addition to the degradation of the crude oil components, a large number of acidic products were detected during the incubation with crude oil, or with crude oil components such as pristane as a model for polymethylsubstituted alkanes, and undecylcyclohexane as a model for alicyclic compounds. Root exudates containing organic acids, amino acids, and carbohydrates can create a specific microenvironment in the root zone system (Kumar et al. 2006), can change the $\mathrm{pH}$ of the environment, and can provide optimal conditions for growth of the rhizosphere microbiota (Gerhardt et al. 2009; Kuiper et al. 2004). In this light, the production of organic acids by M. spathulata SBUG-Y 2180 in the soil may also benefit the development of other microorganisms, and thus contribute to the growth increases of barley seen in the inoculation experiments.

In turn, the presence of barley increased the development of the yeast M. spathulata SBUG-Y 2180, as seen by the 19\% higher number of CFUs in the assay with barley, M. spathulata SBUG-Y 2180, and oil as compared to the assay without barley. Thus, M. spathulata SBUG-Y 2180 and barley may be powerful partners in the interaction with oil pollutants of soil, and hence for bioremediation of oilpolluted areas. Barley grown on contaminated sites can subsequently be used for the production of bio-gas or bio-fuels (Gatta et al. 2013; Neves et al. 2006; Qureshi et al. 2014; Yang et al. 2015).

Supplementary Information The online version contains supplementary material available at https://doi.org/10.1007/s00253-020-11011-1.

Acknowledgments We thank R. Jack (Prof. Emeritus, Institute of Immunology, University of Greifswald) for help in preparing the manuscript. We thank CABNET (Central Asian Biodiversity Network), in particular the project manager Michael Manthey (Institute of Botany and Landscape Ecology, University of Greifswald), for the opportunity to establish active contacts between scientists from the Al-Farabi Kazakh National University and the University of Greifswald.

Contributions of the authors $\mathrm{AM}$ and RB conceived and designed the research. AM, AO, AR, DZ, MM, and FS conducted the experiments. $\mathrm{AM}, \mathrm{RB}, \mathrm{DZ}$, and TM analyzed the data. AM wrote the manuscript. TM, $\mathrm{KR}, \mathrm{TU}$, and FS provided the basis for the research work.

Funding Open Access funding enabled and organized by Projekt DEAL. This study was funded by DAAD (Deutscher Akademischer Austauschdienst) (project code 50754935, project title "CABNETCentral Asian Biodiversity Network," and project code 57525256, project title "Mikrobielle Diversität von kasachischen schadstoffbelasteten Böden und Möglichkeiten der Rekultivierung”).

\section{Compliance with ethical standards}

Conflict of interest The authors declare that they have no conflict of interest.

Ethical approval This article does not contain any studies with human participants or animals performed by any of the authors.

Open Access This article is licensed under a Creative Commons Attribution 4.0 International License, which permits use, sharing, adaptation, distribution and reproduction in any medium or format, as long as you give appropriate credit to the original author(s) and the source, provide a link to the Creative Commons licence, and indicate if changes were made. The images or other third party material in this article are included in the article's Creative Commons licence, unless indicated otherwise in a credit line to the material. If material is not included in the article's Creative Commons licence and your intended use is not permitted by statutory regulation or exceeds the permitted use, you will need to obtain permission directly from the copyright holder. To view a copy of this licence, visit http://creativecommons.org/licenses/by/4.0/.

\section{References}

Afgan E, Baker D, Batut B, van den Beek M, Bouvier D, Cech M, Chilton J, Clements D, Coraor N, Gruning BA, Guerler A, Hillman-Jackson J, Hiltemann S, Jalili V, Rasche H, Soranzo N, Goecks J, Taylor J, Nekrutenko A, Blankenberg D (2018) The Galaxy platform for accessible, reproducible and collaborative biomedical analyses: 2018 update. Nucleic Acids Res 46(W1):W537W544. https://doi.org/10.1093/nar/gky379

Altschul SF, Gish W, Miller W, Myers EW, Lipman DJ (1990) Basic local alignment search tool. J Mol Biol 215(3):403-410. https://doi. org/10.1006/jmbi.1990.9999

Awe S, Mikolasch A, Hammer E, Schauer F (2008) Degradation of phenylalkanes and characterization of aromatic intermediates acting as growth inhibiting substances in hydrocarbon utilizing yeast Candida maltosa. Int Biodeterior Biodegrad 62(4):408-414. https://doi.org/10.1016/j.ibiod.2008.03.007

Beam HW, Perry JJ (1974) Microbial degradation and assimilation of $n$ alkyl-substituted cycloparaffins. J Bacteriol 118(2):394-399

Bos P, de Bruyn JC (1973) The significance of hydrocarbon assimilation in yeast identification. Antonie Van Leeuwenhoek 39(1):99-107. https://doi.org/10.1007/bf02578845

Chevron.com (2020) Tengiz expansion - supersizing the output of a supergiant field. PUblisher. Accessed 21.04. 2020

Ching TH, Yoza BA, Wang RJ, Masutani S, Donachie S, Hihara L, Li QX (2016) Biodegradation of biodiesel and microbiologically induced corrosion of 1018 steel by Moniliella wahieum Y12. Int Biodeterior Biodegrad 108:122-126. https://doi.org/10.1016/j. ibiod.2015.11.027

Cox J, Mann M (2008) MaxQuant enables high peptide identification rates, individualized p.p.b.-range mass accuracies and proteomewide protein quantification. Nat Biotechnol 26(12):1367-1372. https://doi.org/10.1038/nbt.1511

Dua M, Singh A, Sethunathan N, Johri AK (2002) Biotechnology and bioremediation: successes and limitations. Appl Microbiol Biotechnol 59(2-3):143-152. https://doi.org/10.1007/s00253-002-1024-6 
Dutta TK, Harayama S (2001) Biodegradation of $n$-alkylcycloalkanes and $n$-alkylbenzenes via new pathways in Alcanivorax sp. strain MBIC 4326. Appl Environ Microbiol 67(4):1970-1974. https:// doi.org/10.1128/aem.67.4.1970-1974.2001

Ekperusi OA, Aigbodion FI (2015) Bioremediation of petroleum hydrocarbons from crude oil-contaminated soil with the earthworm: Hyperiodrilus africanus. 3. Biotech 5(6):957-965. https://doi.org/ 10.1007/s13205-015-0298-1

Eymann C, Lassek C, Wegner U, Bernhardt J, Fritsch OA, Fuchs S, Otto A, Albrecht D, Schiefelbein U, Cernava T, Aschenbrenner I, Berg G, Grube M, Riedel K (2017) Symbiotic interplay of fungi, algae, and bacteria within the lung lichen Lobaria pulmonaria L. Hoffm as assessed by state-of-the-art metaproteomics. J Proteome Res 16(6): 2160-2173. https://doi.org/10.1021/acs.jproteome.6b00974

Farag S, Soliman NA (2011) Biodegradation of crude petroleum oil and environmental pollutants by Candida tropicalis strain. Braz Arch Biol Technol 54(4):821-830. https://doi.org/10.1590/s151689132011000400023

Gailiūtè I, Kavaliauskè M, Aikaitè-Stanaitienè J (2011) Changes in total oil hydrocarbon composition during degradation with sorbent bacterial preparation. Biologija 57:70-77

Gargouri B, Mhiri N, Karray F, Aloui F, Sayadi S (2015) Isolation and characterization of hydrocarbon-degrading yeast strains from petroleum contaminated industrial wastewater. Biomed Res Int 2015:111. https://doi.org/10.1155/2015/929424

Gatta G, Gagliardi A, Soldo P, Monteleone M (2013) Grasses and legumes in mixture: an energy intercropping system intended for anaerobic digestion. Ital J Agron 8(1):47-57. https://doi.org/10.4081/ ija.2013.e7

Gerhardt KE, Huang X-D, Glick BR, Greenberg BM (2009) Phytoremediation and rhizoremediation of organic soil contaminants: potential and challenges. Plant Sci 176(1):20-30. https://doi. org/10.1016/j.plantsci.2008.09.014

GlobalData.com (2020) Tengiz oilfield - hydrocarbon technology. PUblisher. Accessed 21.04. 2020

Green KD, Turner MK, Woodley JM (2000) Candida cloacae oxidation of long-chain fatty acids to dioic acids. Enzym Microb Technol 27(3-5):205-211. https://doi.org/10.1016/s0141-0229(00)00217-9

Huerta-Cepas J, Forslund K, Coelho LP, Szklarczyk D, Jensen LJ, von Mering C, Bork P (2017) Fast genome-wide functional annotation through orthology assignment by eggNOG-mapper. Mol Biol Evol 34(8):2115-2122. https://doi.org/10.1093/molbev/msx 148

Huerta-Cepas J, Szklarczyk D, Heller D, Hernandez-Plaza A, Forslund SK, Cook H, Mende DR, Letunic I, Rattei T, Jensen LJ, von Mering C, Bork P (2019) eggNOG 5.0: a hierarchical, functionally and phylogenetically annotated orthology resource based on 5090 organisms and 2502 viruses. Nucleic Acids Res 47(D1):D309D314. https://doi.org/10.1093/nar/gky1085

Ivanova AA, Vetrova AA, Filonov AE, Boronin AM (2015) Oil biodegradation by microbial-plant associations. Appl Biochem Microbiol 51(2):196-201. https://doi.org/10.1134/s0003683815020064

Joo HS, Ndegwa PM, Shoda M, Phae CG (2008) Bioremediation of oilcontaminated soil using Candida catenulata and food waste. Environ Pollut 156(3):891-896. https://doi.org/10.1016/j.envpol. 2008.05.026

Juwarkar AA, Singh SK, Mudhoo A (2010) A comprehensive overview of elements in bioremediation. Rev Environ Sci Biotechnol 9(3): 215-288. https://doi.org/10.1007/s11157-010-9215-6

Khorasani AC, Mashreghi M, Yaghmaei S (2013) Study on biodegradation of Mazut by newly isolated strain Enterobacter cloacae BBRC10061: improving and kinetic investigation. Iran J Environ Health Sci Eng 10(1):2-9. https://doi.org/10.1186/1735-2746-10-2

Kitcha S, Cheirsilp B (2013) Enhancing lipid production from crude glycerol by newly isolated oleaginous yeasts: strain selection, process optimization, and fed-batch strategy. Bioenergy Res 6(1):300 310. https://doi.org/10.1007/s12155-012-9257-4
Kuiper I, Lagendijk EL, Bloemberg GV, Lugtenberg BJ (2004) Rhizoremediation: a beneficial plant-microbe interaction. Mol Plant-Microbe Interact 17(1):6-15. https://doi.org/10.1094/MPMI. 2004.17.1.6

Kumar R, Pandey S, Pandey A (2006) Plant roots and carbon sequestration. Curr Sci 91(7):885-890

Kurtzman C, Fell JW, Boekhout T (2011) The yeasts: a taxonomic study. In: Kurtzman C, Fell JW, Boekhout T (eds) . https://doi.org/10. 1111/j.1365-2672.1996.tb03519.x

Margesin R, Schinner F (2001) Biodegradation and bioremediation of hydrocarbons in extreme environments. Appl Microbiol Biotechnol 56(5-6):650-663

Middelhoven WJ (1993) Catabolism of benzene compounds by ascomycetous and basidiomycetous yeasts and yeastlike fungi. Antonie Van Leeuwenhoek 63(2):125-144. https://doi.org/10.1007/bf00872388

Mikolasch A, Omirbekova A, Schumann P, Reinhard A, Sheikhany H, Berzhanova R, Mukasheva T, Schauer F (2015) Enrichment of aliphatic, alicyclic and aromatic acids by oil-degrading bacteria isolated from the rhizosphere of plants growing in oil-contaminated soil from Kazakhstan. Appl Microbiol Biotechnol 99(9):4071-4084. https://doi.org/10.1007/s00253-014-6320-4

Mikolasch A, Reinhard A, Alimbetova A, Omirbekova A, Pasler L, Schumann P, Kabisch J, Mukasheva T, Schauer F (2016) From oil spills to barley growth - oil-degrading soil bacteria and their promoting effects. J Basic Microbiol 56(11):1252-1273. https://doi.org/10. 1002/jobm.201600300

Mikolasch A, Donath M, Reinhard A, Herzer C, Zayadan B, Urich T, Schauer F (2019) Diversity and degradative capabilities of bacteria and fungi isolated from oil-contaminated and hydrocarbon-polluted soils in Kazakhstan. Appl Microbiol Biotechnol 103(17):72617274. https://doi.org/10.1007/s00253-019-10032-9

Morgan P, Watkinson RJ (1994) Biodegradation of components of petroleum. In: Ratledge C (ed) Biochemistry of microbial degradation. Kluwer Academic Publishers, Dordrecht, pp 1-31

Neves L, Ribeiro R, Oliveira R, Alves MM (2006) Enhancement of methane production from barley waste. Biomass Bioenergy 30(6): 599-603. https://doi.org/10.1016/j.biombioe.2005.12.003

Nhi-Cong LT, Mikolasch A, Klenk H-P, Schauer F (2009) Degradation of the multiple branched alkane 2,6,10,14-tetramethyl-pentadecane (pristane) in Rhodococcus ruber and Mycobacterium neoaurum. Int Biodeterior Biodegrad 63(2):201-207. https://doi.org/10.1016/j. ibiod.2008.09.002

Nhi-Cong LT, Mikolasch A, Awe S, Sheikhany H, Klenk H-P, Schauer F (2010) Oxidation of aliphatic, branched chain, and aromatic hydrocarbons by Nocardia cyriacigeorgica isolated from oil-polluted sand samples collected in the Saudi Arabian Desert. J Basic Microbiol 50(3):241-253. https://doi.org/10.1002/jobm.200900358

Pala C (2001) Kazakhstan field's riches come with a price. The St Petersburg Times. vol 715. https://web.archive.org/web/ 20131229133421/http://www.sptimes.ru/story/5705?page = 1\#top, https:/web.archive.org/web/20131229133421/http://www.sptimes. ru/story/5705 ?page = 2\#top, https://web.archive.org/web/ 20131229133421/http://www.sptimes.ru/story/5705?page = 3\#top, Archived from the original on 2013-12-28

Perez-Riverol Y, Csordas A, Bai JW, Bernal-Llinares M, Hewapathirana S, Kundu DJ, Inuganti A, Griss J, Mayer G, Eisenacher M, Perez E, Uszkoreit J, Pfeuffer J, Sachsenberg T, Yilmaz S, Tiwary S, Cox J, Audain E, Walzer M, Jarnuczak AF, Ternent T, Brazma A, Vizcaino JA (2019) The PRIDE database and related tools and resources in 2019: improving support for quantification data. Nucleic Acids Res 47(D1):D442-D450. https://doi.org/10.1093/nar/gky1106

Pirnik MP, McKenna EJ (1977) Microbial oxidation of methyl branched alkanes. Crit Rev Microbiol 5(4):413-422. https://doi.org/10.3109/ 10408417709102812

Qureshi N, Cotta MA, Saha BC (2014) Bioconversion of barley straw and corn stover to butanol (a biofuel) in integrated fermentation and 
simultaneous product recovery bioreactors. Food Bioprod Process 92(C3):298-308. https://doi.org/10.1016/j.fbp.2013.11.005

Ratledge C (1978) Degradation of aliphatic hydrocarbons. In: Watkinson RJ (ed) Developments in biodegradation of hydrocarbons, vol 1. Applied Science, London, pp 1-46

Romero MC, Hammer E, Cazau MC, Arambarri AM (2002) Isolation and characterization of biarylic structure-degrading yeasts: hydroxylation potential of dibenzofuran. Environ Pollut 118(3):379-382. https://doi.org/10.1016/s0269-7491(01)00290-1

Rontani JF, Bonin P (1992) Utilization of $n$-alkyl-substituted cyclohexanes by a marine Alcaligenes. Chemosphere 24(10):1441-1446. https://doi.org/10.1016/0045-6535(92)90266-t

Rosa CA, Jindamorakot S, Limtong S, Nakase T, Lachance MA, FidalgoJimenez A, Daniel HM, Pagnocca FC, Inacio J, Morais PB (2009) Synonymy of the yeast genera Moniliella and Trichosporonoides and proposal of Moniliella fonsecae sp nov and five new species combinations. Int J Syst Evol Microbiol 59:425-429. https://doi. org/10.1099/ijs.0.65117-0

Russo F, Ceci A, Maggi O, Siciliano A, Guida M, Papini MP, Cernik M, Persiani AM (2019) Understanding fungal potential in the mitigation of contaminated areas in the Czech Republic: tolerance, biotransformation of hexachlorocyclohexane $(\mathrm{HCH})$ and oxidative stress analysis. Environ Sci Pollut Res 26(24):24445-24461. https://doi.org/10.1007/s11356-019-05679-w

Schauer F, Schauer M (1986) Alkanassimilierende Hefen. Systematische Stellung und Erfassung einiger Leistungsgrenzen (Alkane assimilating yeasts. Systematic position and determination of some physiological limitations). Wiss Z Ernst-Moritz-Arndt-Univ Greifswald Math-Natwiss Reihe (35):14-23

Schlüter R, Lippmann R, Hammer E, Salazar MG, Schauer F (2013) Novel insights into the fungal oxidation of monoaromatic and biarylic environmental pollutants by characterization of two new ring cleavage enzymes. Appl Microbiol Biotechnol 97(11):50435053. https://doi.org/10.1007/s00253-013-4742-z

Seeliger HPR (1956) Use of a urease test for the screening and identification of cryptococci. J Bacteriol 72(2):127-131

Sietmann R, Hammer E, Moody J, Cerniglia CE, Schauer F (2000) Hydroxylation of biphenyl by the yeast Trichosporon mucoides.
Arch Microbiol 174(5):353-361. https://doi.org/10.1007/ s002030000219

Sietmann R, Gesell M, Hammer E, Schauer F (2006) Oxidative ring cleavage of low chlorinated biphenyl derivatives by fungi leads to the formation of chlorinated lactone derivatives. Chemosphere 64(4):672-685. https://doi.org/10.1016/j.chemosphere.2005.10.050

Stanke M, Diekhans M, Baertsch R, Haussler D (2008) Using native and syntenically mapped cDNA alignments to improve de novo gene finding. Bioinformatics 24(5):637-644. https://doi.org/10.1093/ bioinformatics/btn013

Ururahy AFP, Marins MDM, Vital RL, Gabardo IT, Pereira N (1998) Effect of aeration on biodegradation of petroleum waste. Rev Microbiol 29(4):254-258. https://doi.org/10.1590/s000137141998000400004

Watkinson RJ, Morgan P (1990) Physiology of aliphatic hydrocarbondegrading microorganisms. Biodegradation 1(2-3):79-92

White TJ, Bruns T, Lee S, Taylor JW (1990) Amplification and direct sequencing of fungal ribosomal RNA genes for phylogenetics. In: Innis MA, Gelfand DH, Sninsky JJ, White TJ (eds) PCR protocols: a guide to methods and applications. Academic Press, Inc., New York, pp 315-322

Yang M, Kuittinen S, Zhang J, Vepsalainen J, Keinanen M, Pappinen A (2015) Co-fermentation of hemicellulose and starch from barley straw and grain for efficient pentoses utilization in acetonebutanol-ethanol production. Bioresour Technol 179:128-135. https://doi.org/10.1016/j.biortech.2014.12.005

Ye CJ, Ching TH, Yoza BA, Masutani S, Li QX (2017) Cometabolic degradation of blended biodiesel by Moniliella wahieum Y12(T) and Byssochlamys nivea M1. Int Biodeterior Biodegrad 125:166169. https://doi.org/10.1016/j.ibiod.2017.09.010

Yurkov AM (2018) Yeasts of the soil - obscure but precious. Yeast 35(5): 369-378. https://doi.org/10.1002/yea.3310

Zinjarde S, Apte M, Mohite P, Kumar AR (2014) Yarrowia lipolytica and pollutants: interactions and applications. Biotechnol Adv 32(5): 920-933. https://doi.org/10.1016/j.biotechadv.2014.04.008

Publisher's note Springer Nature remains neutral with regard to jurisdictional claims in published maps and institutional affiliations. 